\title{
FOETAL HAEMOGLOBIN (HbF) STATUS IN ADULT SICKLE CELL ANAEMIA PATIENTS IN IBADAN, NIGERIA.
}

\author{
*J.A. Olaniyi; tO.G Arinola; ++A.B. Odetunde
}

*Department of Haematology, University College Hospital, Ibadan, Nigeria

+Department of Chemical Pathology; University College Hospital, Ibadan, Nigeria

++ IMRAT, College of Medicine, University of Ibadan.

Correspondence:

Olaniyi J.A.

Department of Haematology

University College Hospital, Ibadan, Nigeria

\begin{abstract}
Aim: - Elevated HbF, among other biological and environmental factors, is responsible for decrease in mortality in sickle cell anaemia (SCA). This study determined the levels of $\mathrm{HbF}$ in adult SCA patients in steady state compared with $\mathrm{HbAA}$ controls. $\mathrm{HbF}$ was discussed in line with the clinical course of the disease so as to emphasize the relevance of hydroxyurea in the management of adult SCA patients.

Materials and methods: - The HbF levels of 66 confirmed SCA patients and $31 \mathrm{HbAA}$ controls were estimated using Betke method and $\mathrm{HbF}$ percentage was calculated using formula: $\% \mathrm{HbF}$ percentage $=A_{413}$ filtrate $\times 100 \mathrm{~A}_{413}$ standard $\times 20$.

Result: - A statistical significant difference in the mean of the levels of $\mathrm{HbF}$ in patients $(5.16 \pm 4.04)$ compared to controls $(1.04 \pm 0.44)$ $(\mathrm{p}=0.000)$ was observed. The mean levels of $\mathrm{HbF}$ for males (4.71 3.49) compared to that of females (4.99) were statistically similar $(\mathrm{p}=0.773)$. It was also observed that the mean $\mathrm{HbF}$ level appears to be declining as age advances. SCA patients were classified to three categories viz: $\mathrm{HbF}<2 \%$ (21.2\% SCA patients); $\mathrm{HbF}$ of $2.1 \%$ $-10 \%,(68.2 \%$ SCA patients); and HbF of $10.1 \%-16 \%,(10.6 \%$ SCA patients).

Conclusion: - Substantial proportion of our patients actually will require treatment with hydroxylurea to stimulate $\mathrm{HbF}$ production especially those with $\mathrm{HbF}$ percentage of $<2$ and some with $\mathrm{HbF}$ percentage of $2.1-10 \%$. HPFH may be considered rare since only $10.6 \%$ had $\mathrm{HbF}$ at the range of $10.1-16 \%$. This study showed that in treating our SCA patients in Nigeria we need to adopt and encourage the use of $\mathrm{HbF}$ activating agents like hydroxyurea or any other safe agent that will be found to stimulate $\mathrm{HbF}$ production in SCD patients.
\end{abstract}

Keywords: Sickle cell anaemia, HbF levels, Hydroxyurea use

\section{INTRODUCTION}

$\mathrm{HbF}\left(\mathrm{F}_{2}\right)$, the main haemoglobin component in the foetus, is present at levels of 65 to $90 \%$ at birth and usually drops to less than $2 \%$ by 6 to 12 months of age $^{(1)}$. HbF levels may also be elevated as a result of genetic abnormalities of haemoglobin production or because of haemopoietic stress.

After birth, the HbF- gama-gene is switched down and the HbA beta-gene is switched on so that adults mainly produce $\mathrm{HbA}\left(\mathrm{C}_{2}{ }_{2}\right)$. After this developmental switch, low levels of $\mathrm{HbF}$ are still produced, and this is distributed heterogeneously with some red cells ( $\mathrm{F}$ cells) expressing more $\mathrm{HbF}$ than others ${ }^{(2)}$. The level of $\mathrm{HbF}$, and the associated proportion of F cells, is a highly heritable trait ${ }^{(3)}$, and within a normal population the distribution of $\mathrm{HbF}$ is much skewed. Most healthy individuals produce $<0.6 \% \mathrm{HbF}$ distributed among $1-7 \% \mathrm{~F}$ cells, but a small proportion (about $2 \%$ ) produce up to $5 \% \mathrm{HbF}$ and $25 \% \mathrm{~F}$ cells and such individuals are said to have heterocellular hereditary persistence of fetal $\mathrm{Hb}(\mathrm{hHPFH})^{(4)}$. SCA patients with high $\mathrm{HbF}$ levels not only have less severe clinical course, but also have mild clinical complications because an increase in haemoglobin $\mathrm{F}$ inhibits polymerization of sickle haemoglobin.

The varying levels of foetal haemoglobin in erythrocytes account for a larger part of clinical heterogene- 
ity observed in patients with sickle cell anaemia ${ }^{(5)}$. It is also a major prognostic factor for several clinical complications. $^{(6,7,8)}$

The strong relationship existing between percentage $\mathrm{HbF}$ level and disease severity in SCA suggests that baseline measurement of percentage $\mathrm{HbF}$ is paramount in predicting important aspects of clinical course and in advocating usage of hydroxyurea, which is in low ebb in Nigeria, in order to achieve as much as $40 \%$ reduction in mortality long observed in SCA by Steinberge et al in $2003^{(9)}$

\section{MATERIALS AND METHODS Subjects}

Ninety seven subjects were enrolled. This included 66 SCA patients in steady state attending Medical Out Patient clinic who were consecutively recruited into the study after an informed consent. Also, 31 consenting healthy, $\mathrm{HbAA}$ adults were enrolled into the study. These were medical health workers or voluntary blood donors.

\section{Sample Collection}

Five milliliters of venous blood was collected by clean venepuncture from each patient via the ante-cubital vein using a plastic syringe with minimum stasis, into commercially prepared concentrations of sequestrene ethylene di-amine tetra-acetic acid (EDTA) bottles. Each sample was mixed gently and thoroughly to ensure anticoagulation and to prevent cell lysis. One milliliter of this blood was used to prepare haemolysate for $\mathrm{HbF}$ estimation and haemoglobin electrophoresis using Cellulose acetate at $\mathrm{pH} 8.6$ to confirm $\mathrm{HbA}$ and HbS status.

\section{Methodology}

Measurement of $\mathrm{HbF}$ was done using the Betke method ${ }^{(10)}$. $\mathrm{HbF}$ percentage was calculated using the formula: $\% \mathrm{HbF}=\mathrm{A}_{413}$ filtrate $\mathrm{x} 100 \mathrm{~A}_{413}$ standard $\mathrm{x}$ 20

\section{Statistical Analysis}

Statistical analysis was performed using SPSS 15.0. Results were expressed as mean \pm SD. The difference between mean was compared using the Student's t test.

\section{RESULTS}

Ninety seven subjects made up of 66 diagnosed SCA (HbS) and 31 normal HbA controls were recruited. In the 66 SCA patients, 28 were males while 38 were females with a mean age of $27.9 \pm 10.4$ (age range 15 to 60 years). The control subjects have a mean age of $30.6 \pm 8.1$ years. There was no statistically significant difference in age of the controls and the patients $(\mathrm{p}=$ $0.314)$.

The mean $\mathrm{HbF}$ level for the control was 1.04 \pm 0.44 (range 0.2-1.7) while the mean for the SCA patients was 5.16 \pm 4.04 . The difference in the mean $\mathrm{HbF}$ when compared was statistically significant $(p=0.000)$. In the SCA patients; the mean for males of 4.71 was slightly lower than the mean for females 4.99 although not statistically significant. $(\mathrm{p}=0.773)$.

While the mean $\mathrm{HbF}$ in the controls fall within normal range of $<1.5 \% ; 45(68.2 \%)$ of the SCA patients has a raised $\mathrm{HbF}$ of within the range of $2.1 \%-10 \%$ and $7(10.6 \%$ ) had $\mathrm{HbF}>10 \%$. (Table2). Table 1 also showed the mean $\mathrm{HbF}$ level per particular age range,

\begin{tabular}{|l|l|l|}
\hline A ge & H b S S & M ean H b F (\%) \\
\hline$<20$ & $11(16.7 \%)$ & $5.05 \pm 3.89$ \\
\hline $20-30$ & $37(56.1 \%)$ & $5.42 \pm 4.22$ \\
\hline $30-40$ & $10(15.2 \%)$ & $3.93 \pm 2.83$ \\
\hline$>40$ & $8(12.1 \%)$ & $3.29 \pm 3.82$ \\
\hline To tal & $66(100 \%)$ & $5.16 \pm 4.04$ \\
\hline
\end{tabular}

T ab le 1: M ean $\mathrm{HbF}$ in different age G roups in SCA patients.

highlighting a steady decline in the mean $\mathrm{HbF}$ levels as age advances.

\section{DISCUSSION}

Foetal haemoglobin, a heritable traits in adults accounting for substantial phenotypic diversity of sickle cell disease; was estimated in both control subjects ( $\mathrm{HbAA}$ and known HbSS patients in steady state for comparison. The mean haemoglobin $\mathrm{F}(\mathrm{HbF})$ level expected in $\mathrm{HbAA}$ controls is supposed to be $<1.5 \%{ }^{(11)}$

\begin{tabular}{|l|l|l|l|l|}
\hline $\begin{array}{l}\text { H b F L eve } 1 \\
\text { Age / ye ars }\end{array}$ & $<2 \%$ & $2.1 \%-10 \%$ & $>10 \%$ & T o ta 1 \\
\hline$<20$ & $1(1.5 \%)$ & $9(13.6 \%)$ & $1(1.5 \%)$ & $14(16.7 \%)$ \\
\hline $21-30$ & $3(7.6 \%)$ & $27(40.9 \%)$ & $5(7.6 \%)$ & $8(56.1 \%)$ \\
\hline $31-40$ & $3(4.5 \%)$ & $7(10.6 \%)$ & $0(0 \%)$ & $7(15.2 \%)$ \\
\hline$>40$ & $5(7.6 \%)$ & $2(3.0 \%)$ & $1(1.5 \%)$ & $8(12.5 \%)$ \\
\hline T o ta 1 & $14(21.2 \%)$ & $45(68.2 \%)$ & $7(10.6 \%)$ & $66(100 \%)$ \\
\hline
\end{tabular}

T able 2:- Shows stratification of Levels of HbF according to degree of elevation and age group in SCD patients. 
and the derived mean of 1.04 in this study was within normal. Earlier studies obtained a mean foetal haemoglobin level of $6.4 \pm 4.0 \%{ }^{(12)}$ and $7.4 \pm 3.6 \%{ }^{(13)}$ but the mean $\mathrm{HbF}$ of 5.16 in this study is slightly lower than both earlier values. However, the mean $\mathrm{HbF}$ of patients obtained in this study is in agreement with previous studies ${ }^{(14)}$. Although, the mean of $\mathrm{HbF}$ in females of 4.99 was slightly higher than that of males (4.71), there was no statistically significant difference $(\mathrm{p}=0.773)$. This finding may not agree with comparative survival curve analysis study which found that male HbSS patients had a better overall prognosis than females ${ }^{(15)}$.Another local study found a statistically higher level of $\mathrm{HbF}$ in males than females. ${ }^{(13)}$

Sickle cell anaemia (SCA) was the first human monogenic disorder to be characterized at the molecular level ${ }^{(16)}$ and up to this moment there is yet to be a cure. It results from the substitution of glutamic acid by valine at position 6 of the beta-chain of haemoglobin. The clinical manifestations of SCD arise from the tendency of sickle haemoglobin to polymerize at reduced oxygen tensions and deform red cells into the characteristic rigid sickle cell shape. Such inflexible red cells cannot pass through the microcirculation efficiently, and this results in anaemia (due to destruction of the red cells) and intermittent vaso-occlusion causing tissue damage and pain ${ }^{(17)}$. This watershed arising from sickled haemoglobin is inhibited in patients with elevated $\mathrm{HbF}$ level.

Although all patients with SCA have exactly the same molecular defect, there is considerable clinical variation, ranging from death in early childhood ${ }^{(18)}$, to a normal life span with few complications ${ }^{(4)}$ due to the influence of genetic modifiers of SCA like co-existence of á -thalassemia ${ }^{(19)}$. Therefore, patients with increased levels of $\mathrm{HbF}$ often tend to have a relatively mild clinical course ${ }^{(20)}$ because $\mathrm{HbF}$ reduces the tendency of HbS to polymerize within the red cell. This highlights the need to determine $\mathrm{HbF}$ along with $\mathrm{HbA}_{2}$ in assisting to differentiate HbSS, HbS-beta-thalassemia and HbS-HPFH and hence determination of $\mathrm{HbA}_{2}$ and $\mathrm{HbF}$ should graduate from research activity to routine tool in order to project the management of SCA to a level where the clinical course among others could be easily predicted at diagnosis.

Genetic studies have established that increased $\mathrm{HbF}$ level may result from rare deletions within the betaglobin gene cluster or from point mutations in the promoters of the fetal gamma-globin genes (hereditary persistence of fetal haemoglobin, HPFH), however, additional loci are known to increase $\mathrm{HbF}$ levels in adult life, which has been identified using combination of genome-wide analysis within a large kindred ${ }^{(21)}$ and within twin pairs $^{(22)}$, leading to identification of two quantitative trait loci (QTL) with major influences on fetal hemoglobin levels in adults. Lettre et al ${ }^{(23)}$ had shown that a significant proportion of the variation in $\mathrm{HbF}$ levels and the frequency of painful crises in patients with SCA, are accounted for by five common single-nucleotide polymorphisms (SNPs) at these loci. A pharmacologic agent, Hydroxyurea, (produced and in use since 1994), and its effectiveness was affirmed when a large multicenter, randomized, double blind placebo study in America of 299 subjects showed that the drug significantly reduced not only the frequency and severity of painful crises, but also the incidence of acute chest syndrome, and blood transfusion requirements ${ }^{(24)}$. Its precise mechanism of action is unknown but it causes an increase in fetal haemoglobin concentrations in most subjects by physically interfering with the polymerization process of deoxyhaemoglobin S. Although hydroxyurea is not a cure for sickle cell disease but it should, at present, be offered to our severely affected SCA patients since the risk of severely symptomatic disease and early death is correlated with the fetal haemoglobin concentration ${ }^{(25)}$. The drug will be beneficial to $21 \%$ of SCA patients in this study whose $\% \mathrm{HbF}$ levels fell below $2 \%$ and some of the $68.2 \%$ with $\% \mathrm{HbF}$ ranging between $2.1 \%-10.0 \%$.

It is highly imperative to always estimate not only the levels of $\mathrm{HbF}$, but also of $\mathrm{HbA}_{2}$ so as to be able to clearly define the clinical course of every sickle cell disease patient. Resource poor countries should be assisted to equip their haemoglobinopathy laboratories to be able to have and use freely, equipments like Isoeletric focusing, High Performance Liquid Chromatographic (HPLC) studies and radial immunodiffusion, that will distinctly separate and quantify all haemoglobin variants.

\section{REFERENCES}

1. Haewon C. Kim, Elias Schwartz. Foetal Haemoglobin. In Williams J. Williams et al; Haematology; 4th Edition 1990. pg 1720-1721

2. Boyer SH, Belding TK, Margolet L, Noyes AN: Fetal hemoglobin restriction to a few erythrocytes (F cells) in normal human adults. Science.(1975; 188:361-363.

3. Gamer C, Tatu J, Reittie T, Littlewood J, Darley S et al. Genetic influences on F cells and other haematologic variables: A twin heritability study. Blood. 2000; 95:342-346.

4. Douglas R. Higgs and William G. Wood: Genetic complexity in Sickle Cell Disease. The National academy of Science of the USA. www.pnas.org- 
cgi-doi-10.1073-pnas.0806633105PNAS 2008; 106 (33): 11595-11596.

5. Bailey K, Morris J, Sergent GR. Foetal Haemoglobin and early manifestation homozygous sickle cell diseases. Arch Dis Child 1972.

6. Molineaux L, Fleming AF, Cornille-Brogger R, Kagan L. Abnormal haemoglobin in the suddan savannah of Nigeria III. Ann Trop Med Parasitol 1979; 73: 301-310

7. Bordin JO, Kerbauy J, Lourenco DM and Sesso R. Level of foetal haemoglobin as an indicator of clinical complications in sickle cell anaemia. Braz J Med Biol Res 1989; 22(11): 1347-1353.

8. Olatunji PO. Sickle cell disease in developing countries: magnitude and challenges 1. Postgrad Doc Afr 2002; 25(3): 61-64.

9. Steinberge MH, Barton F, Castro O, Pegelow CH, Ballas SK Kutlar A et al. Effect of hydroxyurea on mortality and morbidity in adult sickle cell anaemia: risks and benefits up to 9 years of treatment. JAMA 2003; 289(13): 1645-51

10. Betke K, Marti HR, Schlicht I: Estimation of small percentage of foetal haemoglobin. Nature 1959; 184: 1877.

11. Samia Zertal-Zidani, Rolande Ducrocg, Mourael Sahbatou et al. Foetal haemoglobin in normal healthy adults with polymorphic sequences cis to the beta globin gene. European Journal of human genetics 2002; 10(5): 320-326.

12. Enosolease ME, Ejele OA, Awodu OA. The influence of foetal haemoglobin on the frequency of vaso-occlusive crisis in sickle cell anaemia patients. Niger Postgrd Med J. 2005; 12(2): 102-5.

13. Kotila TR, Fawole OI, Shokunbi WA. Haemoglobin $\mathrm{F}$ and clinical severity of sickle cell anaemia among Nigerian adults. Afr J Med Sci. 2000; 29(34):229-31.

14. Falusi AG and Esan GJF. Foetal haemoglobin in sickle cell anaemia in Nigerians. Afr J Med Sci 1989; 19: 145-149.

15. Vrudhula K Murphy and L Julian Haywood. Comparative survival curve analysis in sickle cell disease. Applied Mathematics and computation 1981; 9(2): 143-152.
16. Pauling L, Itano HA, Singer SJ, Wells IG: Sicklecell anemia, a molecular disease. Science 1949; 110:543-548.

17. Bunn HF: Pathogenesis and treatment of sickle cell disease. N Engl J Med 1997; 337:762-769.

18. Leikin SL, Gallagher D, Kinney TR, Sloane D, Klug P, Wasima R. Mortality in children and adolescents with sickle cell disease. Cooperative Study of Sickle Cell Disease. Pediatrics. 1989; 84: 500508.

19. Serjeant GR, Higgs DR, Hambleton IR. Elderly survivors with homozygous sickle cell disease. $\mathrm{N}$ Engl J Med. 2007; 356: 642-643.

20. Higgs DR, Aldridge BE, Lamb J, Clegg JB, Weatherall DJ, Hayes RJ, Lowrie J. et al. The interaction of _-thalassemia and homozygous sicklecell disease. N Engl J Med. 1982; 306: 1441-1446.

21. Thein SL, Sampietro M, Rohde K, Rochette J, Weatherall DJ, Lathrop GM, Demenais F. Detection of major gene for hetrocellular hereditary persistence of foetal haemoglobin after accounting for genetic modifiers. American Journal of $\mathrm{Hu}$ man Genetics. 1994; 54: 241-228.

22. Menzel S, Garner C, Gut I, Matsuda F Yamaguchi M Heath S, Foglio M, et al. A QTL influencing F cell production maps to a gene encoding a zincfinger protein on chromosome 2p15. Nat Genet. 2007; 39:1197-1199.

23. Lettre G, Sankaran VG, Bezerra MA,Araujo AS, Uda M, Sanna S, Cao A, Schiessinger D et al. DNA polymorphisms at the BCL11A, HBSIL-MYB, and --globin loci associate with fetal hemoglobin levels and pain crises in sickle cell disease. Proc Natl Acad Sci USA. 2008; 105:11869-11874.

24. Charache S, Terrin ML, Moore DR, Dover DJ, Barton FB, Eckert SV et al. Effect of hydroxyurea on frequency of painful crisis in sickle cell anaemia. N Engl J Med 1995; 33: 1317-1322.

25. Platt OS, Brambilla DJ, Milner PF, Rosse WF,Vichinsky E. et al. Pain in sickle cell disease, rates and risk factors. N Engl J Med 1991; 325: $11-16$ 